\title{
When Courts do Politics: Public Interest Law and Litigation in East Africa by J Oloka- Onyango
}

\author{
Melissa Mungai
}

\section{Introduction}

An all-too-simplistic appreciation of the relationship among the three arms of government should be excluded in order to get the gist of Oloka's writing. He pulls apart the idea that courts simply interpret the law, keeping off from legislative and executive duties. Instead, the author introduces the notion that courts are not insulated from the 'waves of politics'. ${ }^{1}$ In this regard, he invites scrutiny of their powers: of judicial review, to declare a law invalid, to appoint and vet judges, and to interpret the constitution. These defy a purist understanding of the classical separation of powers theory which holds that 'judges should just judge' and in this sense avoid upsetting the status quo. ${ }^{2}$

From the onset, Oloka explains why Public Interest Litigation (PIL) is the fitting lens through which East African ${ }^{3}$ courts' political role can be observed:

'Precisely because PIL is ultimately aimed at the collective and not simply for individual benefit or empowerment, it has powerful potential for organising those affected by a particular law or government action and for ultimately fostering social change. It is in focusing on the collective that PIL crosses over from the purely personal to become political'. ${ }^{4}$

Notably, he draws attention to the limitations of this perspective in particular its reliance on weak or compromised enforcement institutions because court-made law is not sustainable. ${ }^{5}$ In his words:

* The author is an LLB student at Strathmore Law School.

1 Oloka-Onyango J, When courts do politics: Public interest law and litigation in East Africa, Cambridge Scholars Publishing, Newcastle, 2017, 4.

2 Oloka-Onyango J, When courts do politics, 5.

3 The author focuses on Kenya, Tanzania and Uganda because 'the legal regime and professions in all three countries are closely linked'. Oloka-Onyango J, When courts do politics, 9.

4 Oloka-Onyango J, When courts do politics, 11.

5 Oloka-Onyango J, When courts do politics, 12. 
'Charges have been made that PIL is an elite project that steers the judiciary away from its traditional functions and into arenas where it has neither the competence nor capacities to do much good...PIL presents an over-inflated vision of possibilities of social change through court-dominated legal action'. ${ }^{6}$

In Oloka's view, PIL is a contested term both in its definition and application. For instance, in India and South Africa where the concept has been extensively developed, PIL was a show of judicial activism garbed with gusto by the courts to fortify citizen's constitutional rights considered to be non-justiciable against the State, and a means of compensating the large-scale dispossessed society occasioned by the apartheid regime respectively. ${ }^{7}$ In the three East African countries $^{8}$ during the post-independence period, 'public interest' was marked out by the idea of national security, a euphemism for regime stability. The author observes that over time PIL in the three countries has developed into a movement, from a doctrine of parliamentary supremacy to an era of constitutional supremacy; from single-party dictatorship to democratic governance. ${ }^{9}$

Therefore, constitutional supremacy is highlighted as one of the key goals of PIL which entails three aspects. ${ }^{10}$ First, that all organs of the state are bound by the constitution. Second, the relationship among the organs of government is characterised by a system of checks and balances which could inadvertently create uncertainty and tension. Lastly, the judiciary has oversight of the exercise of state power specifically through judicial review as laid down in the constitution. Oloka points out that the third power is inherently a political activity which forces members of the bench to decide what side of the divide (activism or restraint) they fall on. ${ }^{11}$ With this, the two other aspects are at risk of becoming utopian because the diverse judges' ideologies could either be fairly consistent or compromised swinging from one end of the spectrum to the other. ${ }^{12}$

Moreover, in Oloka's viewpoint the three arms of the state are in a constant hegemonic struggle which could be benign and sometimes violent. ${ }^{13}$ Further, that nowhere are these tensions clearest than in PIL because of the effects it has on doctrines that have stood the test of time such as locus standi, the Political

Oloka-Onyango J, When courts do politics, 12.

Oloka-Onyango J, When courts do politics, 91-101.

Kenya, Uganda and Tanzania are the main countries of concern. Oloka-Onyango J, When courts do politics, 9.

Oloka-Onyango J, When courts do politics, 7 and 101-111.

Oloka-Onyango J, When courts do politics, 7-8.

Oloka-Onyango J, When courts do politics, 8-9.

Oloka-Onyango J, When courts do politics, 9 .

Oloka-Onyango J, When courts do politics, 9. 
Question Doctrine and in response to living realities such as gender, economic, social and cultural rights (ESCRs), contested presidential elections and causelawyering. Each of these makes for the different sections in this review where they are expounded on. Whereas locus standi and the Political Question Doctrine set out the conceptual premises upon which Oloka's authorship is based, the living realities exemplify the often-neglected yet critical concerns of PIL in action. Lastly, this article concludes with some reflections on the book.

\section{PIL and Locus Standi}

The right to be heard before the East African courts is a legacy of English common law which dictates that for an individual to gain access to a judicial body, they have to prove a direct, special or peculiar link with the dispute before the courts look into the merits of the case. ${ }^{14}$ Without a doubt, more than outstanding persuasive skills are needed to prove that a mere citizen has direct, special or peculiar connections with a public interest matter. Thus, Oloka describes how the courts dismissed PIL cases based on this procedural technicality without batting an eyelid. He explains that locus standi is prominent because of the three theories that underpin it: proximity of a litigant to the dispute thus excluding the unconcerned third parties, prevention of abuse of court processes through frivolous and vexatious suits, and discouraging the opening of floodgates such that individuals are mindful of the finite court resources (time, costs and expertise). ${ }^{15}$

It is within this trail of thought that the author proceeds to depict locus standi as a tool of imperialism rooted in the English Crown. The Crown took advantage of the various procedural legal hurdles created by the right of standing. By vesting itself with personal ownership of the courts which later evolved into a writ system of adjudication where no negotiation was permitted (no writ, no remedy), justice effectively became a mirage. ${ }^{16}$ Consequently, access to courts became conditional on rigid status-related qualifications like class, gender and property holdings. ${ }^{17}$ Gradually, locus standi morphed into a tyranny of the few with its attendant sovereign immunity from court proceedings furnishing governments carte blanche to act with impunity. ${ }^{18}$

\footnotetext{
Oloka-Onyango J, When courts do politics, 27.

Oloka-Onyango J, When courts do politics, 27.

Oloka-Onyango J, When courts do politics, 29.

Oloka-Onyango J, When courts do politics, 29.

Oloka-Onyango J, When courts do politics, 31 .
} 
Oloka writes that this tool of imperialism was carried down to English colonies in blatant disregard of the established justice systems in the African communities and then carried over into independence as a 'flawed inheritance'. ${ }^{19}$ In his words, 'African societies largely employed egalitarian dispute resolution mechanisms that were spaces of negotiation in which different groups could contest the application of law to their particular circumstances' ${ }^{20}$ Further, the pre-colonial African's right to be heard was neither dominated by procedural considerations nor conditional on their status. ${ }^{21}$ The colonial system rendered these African justice systems as inferior negating the pluralistic character of customary law by moulding them into a single static unit for effective colonial governance. ${ }^{22}$ For that reason, customary law in East Africa remained underdeveloped to pave the way for the emergence of common law. ${ }^{23}$

In spite of gaining independence, Oloka describes how common law still held a vice-like grip over the decisions in East African courts fuelled and legitimised by the repugnancy clauses which substantially modified customary norms to fit into the colonial ideas of 'civilised' behaviour. ${ }^{24}$ In the author's view, this led to judicial redefining of 'public interest' to whatever was in keeping with colonial justice and morality ironically excluding the 'public' (and their accepted customary laws) it ought to have been protecting. ${ }^{25}$ Of interest, he writes that even when all three countries had written constitutions, their judgements reflected parliamentary supremacy and the subordination of judicial power to the two other arms of government and the whims of the ruling party. ${ }^{26}$ Therefore, unsolicited judicial restraint became the primary method of adjudication bestexplained in Egerton $v$ Brownlow:

'It is the province of the judge to expound the law only; the written from the statutes; the unwritten or common law from decisions of our predecessors and of our existing courts, from text-writers of acknowledged authority, and upon the principles to be clearly deduced from them by sound reason and just inference; not to speculate upon what is best, in his opinion, for the advantage of the community'. ${ }^{27}$

Oloka-Onyango J, When courts do politics, 31.

Oloka-Onyango J, When courts do politics, 23.

Oloka-Onyango J, When courts do politics, 23.

Oloka-Onyango J, When courts do politics, 26.

Oloka-Onyango J, When courts do politics, 40.

Oloka-Onyango J, When courts do politics, 30.

Oloka-Onyango J, When courts do politics, 82-83.

Oloka-Onyango J, When courts do politics, 40.

Oloka-Onyango J, When courts do politics, 33. 
Even so, the courts in Uganda, Kenya and Tanzania set their sights on using PIL cases as means to foster constitutional supremacy thus their decisions specifically showed their disdain for single-party civilian dictatorship. In this regard, Oloka draws attention to the celebrated dictum by (then) Chief Justice Udoma in the 1966 case of Uganda v Commissioner of Prisons exparte Matovu which centred on the legitimacy of the Ugandan constitution. Notwithstanding the numerous procedural errors that could cripple the whole case, the court held: 'We decided, in the interests of justice, to jettison formalism to the winds and to overlook the several deficiencies in the application, and thereupon proceeded to the determination of the issues referred to us'. ${ }^{28}$

An enduring trend in 'jettisoning of formality', Oloka writes, led to judicial relaxation of locus standi rules and constitutional reforms in the three countries which culminated with the redefining of 'public interest' to signify 'transformative constitutionalism'. ${ }^{29}$ For instance, the Kenyan bench in the 2010 constitutional petition of Priscilla Nyokabi Kanyua v Attorney General \& Independent Electoral Commission held: 'The issue of locus standi has shackled public law litigants for a long time... and in this way there is merit in one person or organisation being able to approach the court on behalf of all those persons whose rights are allegedly infringed'. ${ }^{30}$

In similar vein, in redefining 'public interest' the East African courts breathed life into constitutional provisions of PIL. The author draws reference to Justice Lugakingira in the famous 1993 Tanzanian case of Reverend Christopher Mtikila v Attorney General whose constitution confers individuals with 'double standing to sue' (personally and as members of the community):

'The orthodox common law position regarding locus standi no longer holds good in the context of constitutional litigation. If a public spirited individual springs up in search of the Court's intervention, the Court as a guardian and trustee of the Constitution must grant him standing. ${ }^{31}$

28 Oloka notes that this only underscored the departure from the common law's strict application of locus standi because the Matovu court eventually upheld Obote's constitution promulgated through an illegal change of government. Fortunately, nonetheless, this later informed drafters of the 1995 Ugandan Constitution, which empowers the court to determine over matters on unconstitutional change of government. See Oloka-Onyango J, When courts do politics, 47.

29 Oloka-Onyango J, When courts do politics, 101-111.

30 Oloka-Onyango J, When courts do politics, 67.

31 Oloka-Onyango J, When courts do politics, 108. 


\section{PIL and the Political Question Doctrine}

Related to locus standi is the Political Question Doctrine (PQD), an American judge-made concept that weeds out cases that negatively impact the judiciary's interaction with the other arms of government. ${ }^{32}$ As Oloka puts it, the judicial body asks itself in a given scenario:

'Is the Judiciary's function primarily aimed at preserving legal order by confining the legislature and executive organs of government within their powers in the interest of the public or is it mainly directed towards the protection of private individuals by preventing illegal encroachments of their individual rights? ${ }^{33}$

Further, because the judiciary 'controls neither purse nor gun-but pen' it necessarily treads carefully in matters outside its discretion. Although, it is deemed to be an outdated doctrine, Oloka's discussion on the PQD, shows how it has broadened and relaxed locus standi rules especially in aspects considered off-limits to the judiciary. ${ }^{34}$ Moreover, he asserts that the biggest problem confronted in developing PIL jurisprudence in East African courts is Executive backlash characterised by scathing remarks directed towards the bench and the enforcement of new policies or laws in obvious contradiction of a judgement. ${ }^{35}$

With this, the author concludes that successful advancing of constitutional supremacy through PIL requires negotiation and compromise with the other arms of government. ${ }^{36}$ This ensures that the judiciary, in exercising its oversight over state power, does not put its institutional integrity at risk due to the inevitable ridiculing and negative reactions by the other arms. ${ }^{37}$

\section{PIL in action}

From the fourth through the seventh and final chapter of the book, Oloka explores the often-neglected topics which in practice have crucially shaped the

32 PQD's origin has been traced by most scholars to American constitutional law and the renowned case of Marbury v Madison where Chief Justice Marshall emphasised that the province of the judicial department is to say what the law is, to decide on the rights of individuals and not to enquire how the Executive perform duties in which they have discretion. See Oloka-Onyango J, When courts do politics, 54-55.

33 Oloka-Onyango J, When courts do politics, 53.

34 Oloka-Onyango J, When courts do politics, 56.

35 Oloka-Onyango J, When courts do politics, 109-111.

36 Oloka-Onyango J, When courts do politics, 111.

37 Oloka-Onyango J, When courts do politics, 111. 
growth of PIL. Thematically, these are not discussed without making reference to the conceptual framework laid out above on locus standi and the PQD. This connected presentation of ideas makes for a richer comprehension of PIL in action in the three East African countries and Oloka's penmanship on the whole.

\section{i. Gender}

Oloka focuses on the impact of the law on relationships between men and women presented in courts as issues of gender-based discrimination in areas like matrimonial property, legislative representation, sexual offences and employment. He writes of 'gender justice' where access to justice in itself is affected by the society's distribution of power, resources and opportunities exemplifying the gendered divide between public and private issues. ${ }^{38}$ Therefore, in the author's opinion, the law by nature must play a critical role in realising the goal of more autonomy for women in two-respects. ${ }^{39}$

From a qualitative angle, he probes into the effectiveness of justice delivered via a court in bringing about enduring social change. ${ }^{40}$ Here, he borrows from the views of former Deputy Chief Justice Rawal that gender-equality as a sociolegal right requires immediate realisation. ${ }^{41}$ But how practical is this? Secondly, from a quantitative perspective, Oloka questions whether the gender make-up of the judiciary alters the way issues between men and women are addressed two of which are peculiar: What do women do once vested with judicial power? Are their actions markedly different from men's?

\section{ii. Economic, social and cultural rights}

By bringing intersectionality in the book resulting in a more robust examination of PIL, the author focuses on the much-contested justiciability of ESCRs. Oloka once again dismisses Montesquieu's theory which posits that the executive and legislature are best-suited to distribute the national purse and an intrusion by the courts in this regard, is undesirable for the sealed and impermeable separation of powers. ${ }^{42}$ Justiciability, a set of judge-made rules, norms and principles delineates whether or not a matter is suitable for judicial determination in social,

\footnotetext{
Oloka-Onyango J, When courts do politics, 114-115.

Oloka-Onyango J, When courts do politics, 114.

Oloka-Onyango J, When courts do politics, 114.

Oloka-Onyango J, When courts do politics, 133.

Oloka-Onyango J, When courts do politics, 5, 62-163.
} 
political and economic contexts. ${ }^{43}$ Such judicial intervention must consider the capacities and legitimacy of the judicial process, the constitutional separation of powers and the nature of the dispute before the court. ${ }^{44}$

PIL judgements concerning ESCR's have proven that ESCRs are justiciable and signify more than the so-called second-cousins to civil and political rights (CPRs). Similar to CPRs, ESCRs disclose positive and negative obligations on the state to ensure certain needs are met and to guarantee that no individual will be arbitrarily deprived of basic necessities respectively. ${ }^{45}$ However, it is much ado about nothing when individuals cannot possess anything in the first place.

Oloka highlights how courts in East Africa have advocated the eradication of poverty in addressing the land question and the protection of the environment which is intrinsically linked to indigenous rights over land (the most valuable resource in the three countries but a major source of conflict). ${ }^{46}$ Uniquely, Oloka provides some insight on the often-neglected cultural rights calling for a return to pluralism where customary law should not be omitted in discussions about poverty and inequality of resources. ${ }^{47} \mathrm{He}$ then suggests that the judicial approach to the realisation of CPRs and ESCRs should not depict a fundamental difference marking an end to the 'contestation'. ${ }^{4}$

\section{iii. Presidential elections}

The perceived role of the courts of law has extended to presidential elections typically excluded from determination by the judiciary. ${ }^{49}$ Oloka is of the view that at the pinnacle of political action, an election, the limit to the courts political role is ultimately reached. This is unpacked drawing from the political histories of the three countries and how their judiciaries intervene in presidential elections. He writes that in Kenya particularly during Moi's regime, election petitions were dismissed on procedural objections while in Uganda during Obote's regime 'judicial nonchalance and compromise was so high that in one instance, a petition filed shortly after the election had not been determined five years later when a new election would have been scheduled'. ${ }^{50}$

\footnotetext{
Oloka-Onyango J, When courts do politics, 163.

Oloka-Onyango J, When courts do politics, 163.

Oloka-Onyango J, When courts do politics, 166.

Oloka-Onyango J, When courts do politics, 88-204.

Oloka-Onyango J, When courts do politics, 207.

Oloka-Onyango J, When courts do politics, 215.

Oloka-Onyango J, When courts do politics, 7.

Oloka-Onyango J, When courts do politics, 228, 236-237.
} 
Despite the now-empowered judiciaries, Oloka concludes that judicial determination of contested presidential elections is a question of judicial bravery. First, the courts operate in an atmosphere of high political tension, time restrictions, legal constraints which cumulatively move them completely out of their comfort zones. ${ }^{51}$ Secondly, they are restricted by legal frameworks when assessing whether election laws and the constitution have been substantially violated. In the writer's view, this leads to half-baked interpretations of a free and fair election; is it possible to quantify acts of intimidation, violence and partisan harassment $?^{52}$ Should a qualitative assessment be the decisive method? In reaction, the courts either rely on the PQD where they avoid upsetting the status quo (even when it means legitimising an unconstitutional change of government) or practice judicial activism in the interests of justice in the hope that the other arms will accept such determination.

\section{iv. Cause-lawyering}

The author defines cause-lawyering as the deployment of legal resources, particularly litigation, to advance progressive social, political or economic causes with a specific focus on the law. ${ }^{53}$ Targeting public-spirited lawyers and attorney generals, he puts forward that their commitments to PIL should clarify on the 'public' they work for (is it the vulnerable minorities or the dominant powerful social actors?) and their personal motivation (is it fame or human-rights activism?) where reimbursement of legal costs is not a given in this type of litigation. ${ }^{54}$ Oloka proceeds to provide some pointers for the future of PIL. Interestingly, he highlights the much-needed role of regular East African law reviews that update on 'status quo-altering judicial pronouncements'. ${ }^{55}$

\section{Concluding Remarks}

The author must be lauded for his herculean effort in analysing three different jurisdictions while at the same time maintaining fidelity to the main thematic areas within the book. It is high time the Judiciary is celebrated not only for its role in Public Interest Litigation but carving out its true identity as

\footnotetext{
Oloka-Onyango J, When courts do politics, 258.

Oloka-Onyango J, When courts do politics, 244.

Oloka-Onyango J, When courts do politics, 260.

Oloka-Onyango J, When courts do politics, 276.

Oloka-Onyango J, When courts do politics, 294.
} 
the custodian of the rule of law even in circumstances that would undermine its relationship with the Executive and the Legislature. In the words of Justice Bhagwati: 'The judiciary is a separate but equal branch of the State with a socioeconomic destination and a creative function'. This book is recommended for agents of social change, from law students to the experienced in legal practice, and for those with an unabated yearning for authentic African jurisprudential wisdom. 